\title{
PENYULUHAN KESEHATAN UNTUK MASYARAKAT DESA LABUHAN BAJO SEBAGAI UPAYA MENINGKATKAN PEMAHAMAN TENTANG BAHAYA STUNTING
}

\author{
Health Counseling for the Community of Labuhan Bajo Village as an Effort to \\ Improve Understanding of Stunting Hazards
}

\author{
Fahmi Yahya, Dwi Mardhia, Dedy Syafikri, Nining Andriani \\ Universitas Samawa (UNSA) \\ Jl. Bypass Sering, Kerato, Unter Iwes, Kabupaten Sumbawa, Nusa Tenggara Barat. 84316 \\ ${ }^{*}$ Alamat korespondensi : fyahyaadam@gmail.com
}

(Tanggal Submission: 26 July 2020, Tanggal Accepted: 2 September 2020)

\begin{abstract}
ABSTRAK
Desa Labuhan Bajo merupakan salah satu desa di wilayah pesisir kecamatan Utan kabupaten Sumbawa. Desa ini termasuk dalam zona merah (masalah berat) kasus stunting (anak kerdil). Pada tahun 2018 , tercatat $28 \%$ balita di Desa ini atau sekitar 68 anak mengalami stunting. Tujuan yang ingin dicapai dalam kegiatan ini adalah terciptanya masyarakat yang sadar akan pentingnya perilaku hidup sehat dan bahaya stunting, sehingga dapat memperbaiki pola hidupnya guna pencegahan dampak buruk stunting. Selain itu, juga bertujuan untuk meningkatkan kesadaran masyarakat untuk memproduksi dan mengkonsumsi garam beryodium. Kegiatan Penyuluhan kesehatan ini dilakukan pada bulan mei tahun 2019. Adapun langkah-langkah kegiatan adalah: (1) berkoordinasi dengan pihak-pihak terkait seperti pemerintah desa Labuhan Bajo, pemerintah kecamatan Utan, dan Dikes kabupaten Sumbawa, (2) melakukan sosialisasi kepada masyarakat tentang rencana kegiatan, (3) mempersiapkan tempat dan kelengkapan selama kegiatan, (4) melakukan penyuluhan kesehatan, dan (5) melakukan evaluasi. Kegiatan ini mendapat respon positif dari pemerintah kecamatan Utan, pemerintah desa Labuhan Bajo, dan juga masyarakat yang mengikuti acara penyuluhan.
\end{abstract}

Keywords : Penyuluhan, Kesehatan, Perilaku Hidup Sehat, Stunting.

\section{PENDAHULUAN}

Desa Labuhan Bajo merupakan salah satu desa di bagian pesisir kabupaten Sumbawa. Desa ini termasuk dalam wilayah kecamatan Utan yang berada pada zona merah (masalah berat) kasus stunting (anak kerdil), yaitu sebanyak 37,09\% angka kejadian. Artinya setiap 2 dari 3 bayi yang lahir di kecamatan Utan beresiko kena stunting. Di desa Labuhan Bajo sendiri, tercatat $28 \%$ balita atau sekitar 68 anak mengalami stunting. Angka ini cukup besar dan harus segera diatasi.

Dikutip dari situs Kemenkes, Stunting adalah kondisi gagal tumbuh pada tubuh dan otak akibat kekurangan gizi dalam waktu yang lama. Sehingga, anak lebih pendek dari anak normal seusianya dan memiliki keterlambatan dalam berpikir. Kekurangan gizi dapat terjadi sejak bayi dalam kandungan dan pada 
masa awal setelah bayi lahir. Akan tetapi, kondisi stunting baru nampak setelah bayi berusia 2 tahun. Menurut Keputusan Menteri Kesehatan Nomor 1995/MENKES/SK/XII/2010, Balita yang dikatakan pendek (stunted) dan sangat pendek (severely stunted) adalah balita dengan panjang badan (PB/U) atau tinggi badan (TB/U) menurut umurnya dibandingkan dengan standar baku WHO-MGRS (Multicentre Growth Reference Study) 2006. Anak balita dikatakan stunting apabila memiliki nilai z-score kurang dari -2SD/standar deviasi (stunted) dan kurang dari-3SD (severely stunted).

Stunting pada anak balita merupakan konsekuensi dari beberapa faktor yang saling berkaitan, yaitu kemiskinan, gizi, kesehatan, sanitasi dan lingkungan (Aridiyah et all, 2015). Tim Nasional Percepatan Penanggulangan Kemiskinan (TNP2K, 2017) merangkum beberapa faktor yang menjadi penyebab stunting, yaitu: (1) Praktek pengasuhan yang kurang baik, termasuk kurangnya pengetahuan ibu mengenai kesehatan dan gizi. (2) Masih terbatasnya layanan kesehatan termasuk layanan ANC-Ante Natal Care (pelayanan kesehatan untuk ibu selama masa kehamilan) Post Natal Care dan pembelajaran dini yang berkualitas. (3) Masih kurangnya akses rumah tangga/keluarga ke makanan bergizi. (4) Kurangnya akses ke air bersih dan sanitasi.

Stunting dapat menimbulkan beberapa dampak buruk lainnya. Dalam jangka pendek adalah terganggunya perkembangan otak, kecerdasan, gangguan pertumbuhan fisik, dan gangguan metabolism dalam tubuh. Sedangkan dalam jangka panjang akibat buruk yang dapat ditimbulkan adalah menurunnya kemampuan kognitif dan prestasi belajar, menurunnya kekebalan tubuh sehingga mudah sakit, dan resiko tinggi untuk munculnya penyakit diabetes, kegemukan, penyakit jantung dan pembuluh darah, kanker, stroke, dan disabilitas pada usia tua (Kemenkes RI, 2016).
Penanganan Stunting dapat dilakukan melalui intervensi spesifik dan intervensi sensitif pada 1000 hari pertama kehidupan anak sampai berusia 6 tahun. Intervensi gizi spesifik dapat berupa memberikan makanan tambahan pada ibu hamil untuk mengatasi kekurangan energi dan protein kronis, mengatasi kekurangan zat besi dan asam folat, mengatasi kekurangan yodium, dan melindungi ibu hamil dari cacingan dan malaria, mendorong pemberian ASI ekslusif, dan memberikan imunisasi lengkap. Sedangkan intervensi gizi sensitive diantaranya menyediakan dan memastikan akses pada air bersih, akses pada sanitasi, melakukan fortifikasi bahan pangan, menyediakan akses pelayanan kesehatan dan keluarga berencana, memberikan Pendidikan pengasuhan pada orang tua, Pendidikan gizi masyarakat, dan juga memberikan edukasi kesehatan seksual dan reproduksi serta gizi pada remaja (Kemenkes RI, 2016).

Salah satu cara penanganan stunting adalah dengan mengatasi kekurangan yodium. Yodium adalah sejenis mineral yang terdapat di alam, baik di tanah, maupun di air, merupakan zat gizi mikro yang diperlukan untuk pertumbuhan dan perkembangan mahluk hidup. Yodium diperlukan untuk membentuk hormon tiroksin yang dimanfaatkan oleh tubuh dalam mengatur pertumbuhan dan perkembangan sejak masih dalam janin hingga dewasa (Devi, 2012). Yodium dapat diperoleh dari mengkonsumsi garam beryodium. Oleh karena itu, perilaku ibu-ibu rumah tangga dalam memilih garam akan menentukan jumlah konsumsi yodium pada rumah tangganya.

Kegiatan pengabdian pada masyarakat ini bertujuan untuk meningkatkan pemahaman masyarakat desa Labuhan Bajo kecamatan Utan tentang perilaku hidup sehat dan bahaya stunting. Agar masyarakat dapat memperbaiki pola hidupnya guna pencegahan dampak buruk stunting. Selain itu, melalui kegiatan ini kami harapkan masyarakat desa Labuhan Bajo kecamatan Utan menjadi lebih sadar 
untuk memproduksi dan mengkonsumsi garam beryodium.

\section{METODE PELAKSANAAN}

Kegiatan pengabdian kepada masyarakat ini merupakan bagian dari rangkaian kegiatan Program Pengembangan Desa Mitra (PPDM) yang berjudul "Pengembangan Desa Labuhan Bajo sebagai Desa Garam Beryodium dalam Rangka Meningkatkan Kualitas Garam dan Mengurangi Angka Kejadian Stunting" yang berlangsung selama 3 tahun sejak tahun 2019 sampai tahun 2021. Adapun kegiatan Penyuluhan Kesehatan Masyarakat ini, dilakukan di tahun pertama, pada bulan mei tahun 2019.

Dalam kegiatan ini, kami sebagai tim pelaksana mempersiapkan segala kelengkapan untuk acara. Yang meliputi, koordinasi dengan pemerintah desa Labuhan Bajo, koordinasi dengan Dikes (Dinas Kesehatan) kabupaten Sumbawa, mempersiapkan undangan untuk masyarakat calon peserta penyuluhan, mempersiapkan tempat dan beberapa kelengkapan lainnya selama acara.

Pembicara utama dalam kegiatan penyuluhan ini didatangkan dari Dikes kabupaten Sumbawa. Sedangkan peserta kegiatan merupakan warga desa Labuhan Bajo yang terdiri dari ibu-ibu rumah tangga, dan juga bapak-bapak yang tergabung dalam kelompok petani garam desa tersebut. Kegiatan penyuluhan dilakukan di Balai Desa Labuhan Bajo.

Untuk mengetahui apakah terdapat peningkatan pemahaman pada peserta penyuluhan, maka kami berikan pretes dan postes, sebelum dan setelah penyuluhan. Selain itu, kami juga melakukan pengamatan pada masyarakat tersebut, apakah terdapat perbaikan perilaku hidup sehat yang lebih baik setelah mendapatkan penyuluhan.

\section{HASIL DAN PEMBAHASAN}

Kegiatan ini diawali dengan koordinasi dengan pemerintah desa Labuhan Bajo. Memetakan masalah dan merencanakan solusi pemecahan masalah tersebut.

Diantara permasalahan yang didapatkan adalah perilaku masyarakat yang kurang baik. Masih terdapat masyarakat yang buang sampah sembarangan, sehingga lingkungan tempat tinggalnya jadi kotor. Sejauh ini peran masyarakat dalam pengelolaan sampah masih sangat minim, dimana masih banyak masyarakat yang belum mau peduli terhadap urusan sampah di lingkungan tempat tinggalnya. Oleh karena itu, dibutuhkan suatu usaha untuk meningkatkan peran aktif masyarakat. Salah satunya melalui penyuluhan. (Mardhia \& Wartiningsih, 2018). Selain sampah, sanitasi juga menjadi permasalahan di Desa Labuhan Bajo. Menurut informasi dari warga, masih terdapat masyarakat yang buang air besar (BAB) di pinggir pantai ketika air laut surut, yang kemudian menyebabkan kotorannya terbawa ke darat ketika air laut sedang pasang menimbulkan bau tidak sedap.
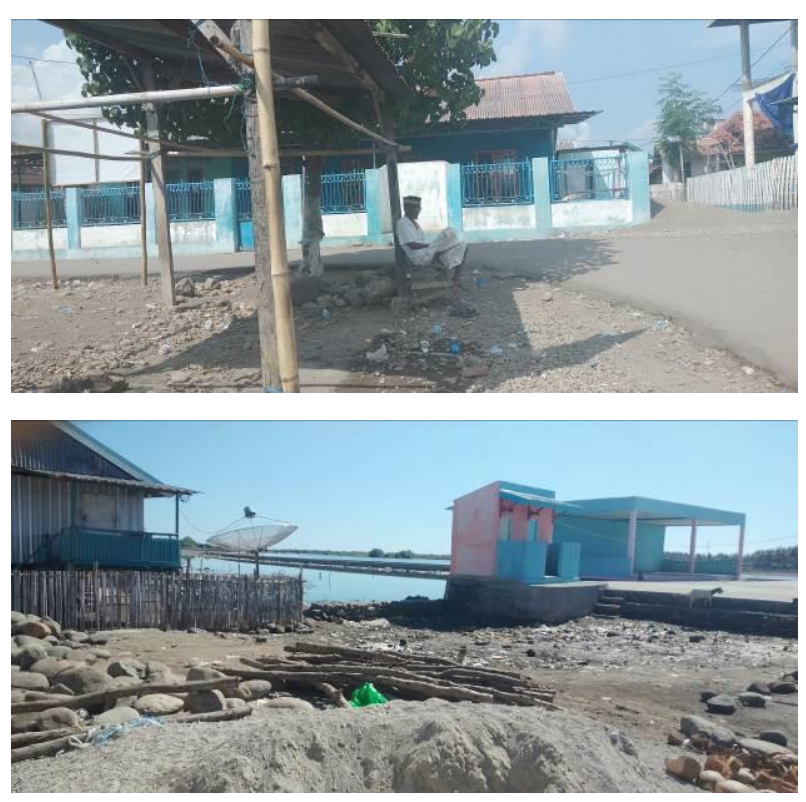

Gambar 1. Kondisi Lingkungan Pesisir Pantai di sekitar Rumah Warga

Selain itu, permasalahan selanjutnya adalah angka kejadian stunting di desa Labuhan Bajo 
termasuk yang tinggi di kabupaten Sumbawa. Dalam data kabupaten Sumbawa, Kecamatan Utan yang di dalamnya termasuk desa Labuhan Bajo bahkan termasuk dalam zona merah (berbahaya). Hal ini menyebabkan tim pelaksana merasa perlu memberikan penyuluhan kesehatan kepada masyarakat desa ini.

Pada tahap persiapan pelaksanaan kegiatan, selain berkoordinasi dengan pemerintah desa, kami juga berkoordinasi dengan pihak kecamatan Utan dan Dikes kabupaten Sumbawa. Koordinasi dengan pihak kecamatan bertujuan untuk mendapatkan dukungan moril dan juga sebagai bentuk pelaporan karena kegiatan ini berada di wilayah pemerintah kecamatan Utan. Sedangkan koordinasi dengan Dikes bertujuan agar mereka dapat mengutus beberapa ahli bidang kesehatan untuk menjadi pemateri tentang perilaku hidup sehat dan Bahaya Stunting.

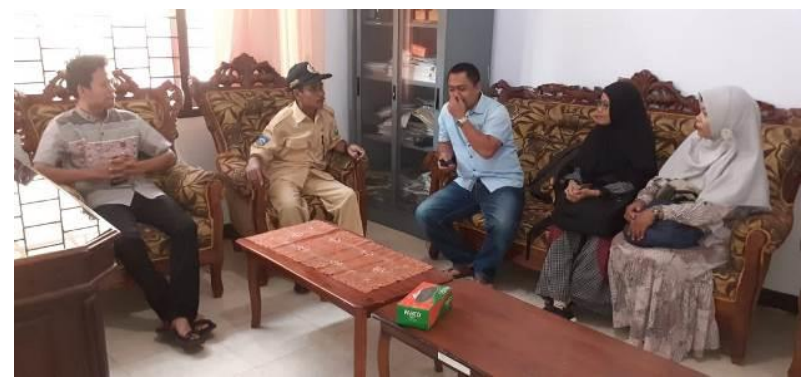

Gambar 2a. Koordinasi dengan pemerintah kec.Utan

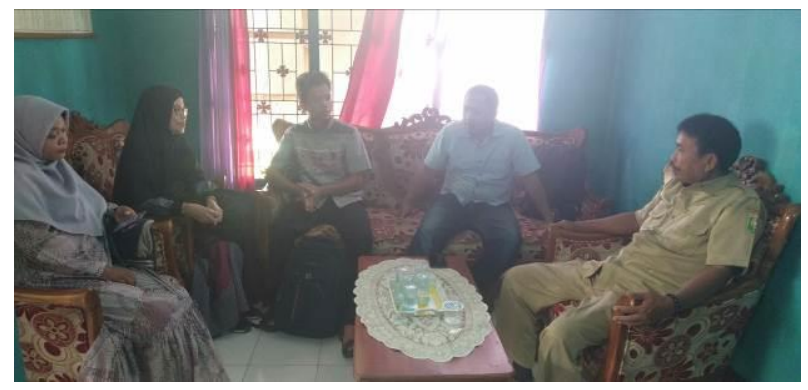

Gambar 2b. Koordinasi dengan pemerintah desa Labuhan Bajo

Penyuluhan kesehatan masyarakat dilakukan di Balai Desa Labuhan Bajo, pada tanggal 2 Mei 2019. Pembicara utama yang diutus oleh Dikes kabupaten Sumbawa adalah dr. NIETA ARIANI. Diantara materi yang disampaikan adalah (1). Perilaku hidup sehat, (2) definisi stunting, (3) faktor-faktor penyebab stunting, (4) dampak stunting (5) cara pencegahan stunting (6) cara mengidentifikasi keberadaan yodium pada garam. Sedangkan tim pengabdian bertugas sebagai sebagai pembicara pendamping sekaligus moderator acara adalah Dwi Mardhia, M.Sc. Diantara materi yang disampaikan adalah (1) latar belakang kegiatan ini, (2) kondisi stunting di Kabupaten Sumbawa pada umumnya dan desa Labuhan Bajo pada khususnya, (3) peran pemerintah dan masyarakat dalam mengatasi stunting, (4) potensi desa Labuhan Bajo dalam mencegah stunting, dan (5) keuntungan-keuntungan dalam memproduksi garam beryodium.

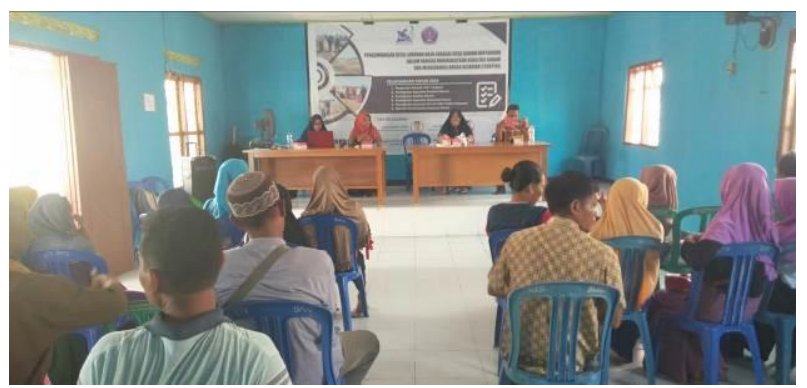

Gambar 3. Suasana saat penyuluhan

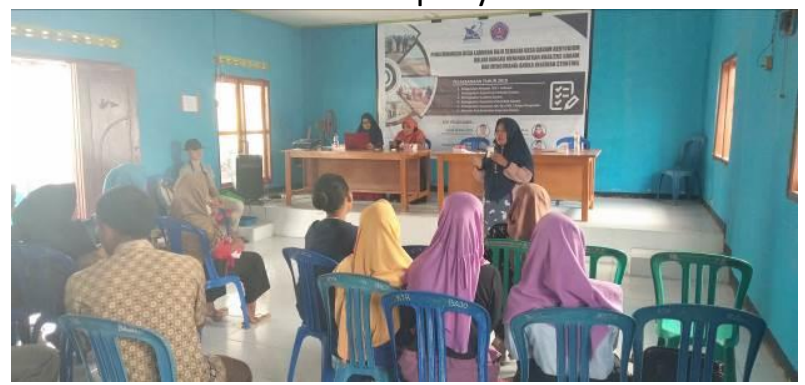

Gambar 4. Penyampaian Materi oleh dr. Nieta

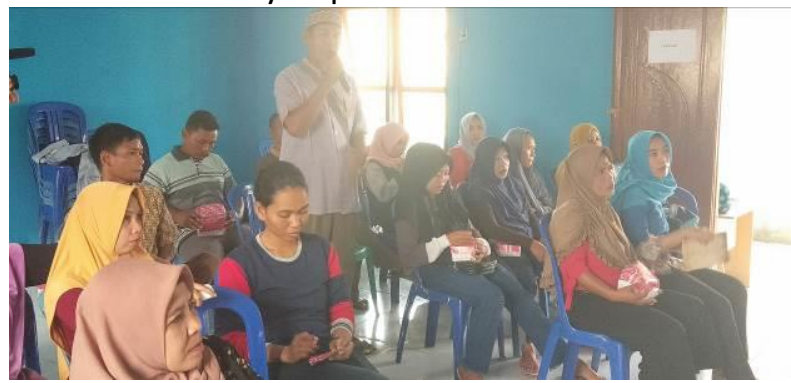

Gambar 5. Peserta bertanya kepada Pemateri

Dalam acara penyuluhan kesehatan ini, peserta tampak antusias mengikuti materi yang diberikan. Masyarakat juga jadi lebih paham tentang stunting, apa saja yang menjadi penyebabnya, 
bagaimana dampak-dampak berbahaya yang ditimbulkan, bagaimana cara mencegah dan juga cara mengobatinya. Selain itu, mereka juga menjadi lebih menyadari tentang pentingnya perilaku hidup sehat. Menjaga kebersihan lingkungan tempat tinggal, memperbaiki sanitasi, pentingnya mengkonsumsi makanan dan minuman bergizi, mengutamakan untuk menggunakan garam beryodium dalam setiap masakan. Hal ini tampak dari hasil pretes dan postes sebelum dan setelah kegiatan penyuluhan.

Masyarakat, pemerintah Desa Labuhan Bajo, dan Pemerintah kecamatan Utan merespon positif kegiatan penyuluhan kesehatan ini. Kegiatan ini dirasa telah menumbuhkan kesadaran mereka tentang perilaku hidup sehat dan bahaya Stunting. Mereka berjanji dan memperhatikan perilaku hidup dan menjaga lingkungan untuk kesehatan kenyamanan bersama. Para anggota kelompok petani garam juga merasakan manfaat yang sangat besar dalam kegiatan ini. Selain lebih memahami tentang cara menjaga keluarga dari bahaya stunting, mereka jadi tahu bagaimana cara mengidentifikasi garam yang mengandung yodium, dan lebih bersemangat untuk mulai memproduksi garam beryodium di masa mendatang. Terlebih setelah dipaparkan bagaimana keuntungan finansial yang mungkin didapatkan dari hasil produksi garam beryodium.

Dua bulan sejak penyuluhan kesehatan yang kami berikan, kami mengamati pola kehidupan masyarakat di desa Labuhan Bajo. Tampak ada perubahan dalam perilaku masyarakat. Kami memperhatikan lingkungan jadi lebih bersih, sampahsampah telah dibuang pada tempatnya. Ibu-ibu rumah tangga mengutamakan memasak menggunakan garam beryodium. Bapak-bapak kelompok petani garam sudah mulai memproduksi garam beryodium.

Pendampingan masyarakat oleh tim pengabdian pada masyarakat ini terus akan dilakukan sampai tahun 2021. Kami ingin memastikan bahwa segala upaya yang mungkin kami lakukan bersama masyarakat dalam mengatasi stunting, dapat terlaksana dengan baik. Harapan kami, desa ini dapat menjadi salah satu desa percontohan dalam mengatasi stunting. Selain itu, kami juga bercita-cita menjadikan desa Labuhan Bajo kecamatan Utan sebagai salah satu desa sentra garam beryodium di kabupaten Sumbawa.

\section{KESIMPULAN DAN SARAN}

Dari hasil kegiatan pengabdian kepada masyarakat ini, dapat disimpulkan beberapa hal sebagai berikut:

1. Pentingnya memberikan penyuluhan kesehatan agar masyarakat lebih memahami tentang perilaku hidup sehat dan bahaya stunting.

2. Peserta penyuluhan menjadi lebih menyadari pentingnya perilaku hidup sehat dan bahaya stunting.

Penulis menyarankan beberapa hal untuk kegiatan selanjutnya, sebagai berikut:

1. Masyarakat harus berpastisipasi secara aktif dan bekerjasama dengan pemerintah desa maupun pemerintah daerah untuk mengatasi masalah bersama seperti masalah lingkungan dan stunting.

2. Masyarakat perlu terus diberikan penyuluhan dan pendampingan agar lebih memahami dan dapat terhindar dari bahaya stunting.

3. Perlu regulasi khusus dari pemerintah desa agar masyarakat dapat menjaga kebersihan lingkungan tempat tinggalnya

\section{UCAPAN TERIMA KASIH}

Ucapan terima kasih pada Kemenristekdikti dan Universitas Samawa sebagai donatur dalam kegiatan pengabdian masyarakat ini. Ucapan terimakasih juga kepada masyarakat desa Labuhan Bajo yang telah berpartisipasi aktif selama kegiatan. Kepada pemerintah desa Labuhan Bajo dan pemerintah kecamatan Utan yang telah memfasilitasi 
kegiatan ini. Serta kepada Dikes kabupaten Sumbawa yang telah membantu selama kegiatan berlangsung.

\section{DAFTAR PUSTAKA}

Aridiyah, F.O., Rohmawati, N., Ririanty, M. (2015). Faktor-faktor yang Mempengaruhi Kejadian Stunting pada Anak Balita di Wilayah Pedesaan dan Perkotaan. e-Jurnal Pustaka Kesehatan, vol 3 (1): 163-170.

Devi, Mazarina. 2012. Hubungan Penggunaan Garam Beryodium Dengan Pertumbuhan Linier Anak. Jurnal TIBBS (Teknologi Industri Boga dan Busana). Vol. 3(1) :52-57.
Kementerian Kesehatan RI (2016). Situasi Balita Pendek. Jakarta: Infodatin

Keputusan Menteri Kesehatan Nomor 1995/MENKES/SK/XII/2010

Mardhia, D., Wartiningsih, A (2018). Pelatihan Pengolahan Sampah Skala Rumah Tangga di Desa Penyaring. Jurnal Pendidikan dan Pengabdian Masyarakat. Vol 1(1) :88-96.

Tim Nasional Percepatan Penanggulangan Kemiskinan. (2017). 100 Kabupaten/Kota Prioritas untuk Intervensi Anak Kerdil (Stunting) Ringkasan. 